\title{
Pola Penggunaan Antibiotik Dalam Swamedikasi Pada Mahasiswa Tahun Pertama Bersama (TPB) Universitas Mataram
}

\author{
Siti Fatmah, Siti Rahmatul Aini*, Iman Surya Pratama \\ Program Studi Farmasi Fakultas Kedokteran Universitas Mataram \\ *Email korespondensi : sitira@unram.ac.id
}

(Submit 15/03/2019, Revisi 05/09/2019, Diterima 20/12/2019)

\section{Abstrak}

Penggunaan antibiotik yang tidak tepat dalam swamedikasi sering terjadi di berbagai kalangan tak terkecuali mahasiswa. Ketidaktepatan penggunaan menyebabkan peningkatan resiko efek samping dan resistensi antibiotik sehingga diperlukan implementasi swamedikasi yang tepat. Studi pola penggunaan obat pada kalangan mahasiswa di Kota Mataram masih terbatas. Penelitian ini bertujuan untuk mendeskripsikan pola penggunaan antibiotik dalam swamedikasi pada mahasiswa TPB Universitas Mataram. Penelitian ini menggunakan desain potong lintang (cross sectional) dengan pendekatan kualitatif dan kuantitatif pada 400 mahasiswa TPB yang dipilih secara acak. Penelitian dilaksanakan pada bulan Maret-Juli 2018 di Unit Pelaksana Tahun Pertama Bersama Universitas Mataram. Data karakteristik demografi dan pola penggunaan antibiotik diperoleh melalui penyebaran kuesioner. Data karakteristik demografi meliputi nama, nim, alamat, asal sekolah, asal fakultas, dan kontak responden. Pola penggunaan antibiotik meliputi alasan penggunaan, indikasi, sumber mendapatkan, lama terapi, dan efek samping Analisis dilakukan secara deskriptif. Dari 421 mahasiswa, 379 pernah menggunakan antibiotik. Mahasiswa terdiri dari 119 laki-laki dan 260 perempuan dengan rata-rata usia 17-18 tahun. Hasil penelitian menunjukkan penggunaan antibiotik untuk mengobati flu dan batuk selama 13 hari $(43 \%)$. Antibiotik diperoleh dengan mudah di apotek berdasarkan rekomendasi tenaga kesehatan $(49,6 \%)$. Antibiotik jika digunakan berlebihan dapat meningkatkan resiko efek samping seperti mual muntah $35,9 \%$. Penggunaan dihentikan jika efek samping terjadi dan berkonsultasi ke dokter $(51,7 \%)$. Penggunaan antibiotik dalam swamedikasi pada mahasiswa TPB masih belum tepat ditinjau dari pola penggunaan antibiotik.

Kata kunci: Mahasiswa TPB, pola penggunaan antibiotik, swamedikasi, Universitas Mataram

\section{Outline}

- Pendahuluan

- Metode

- Hasil dan Pembahasan

- Kesimpulan

- Daftar Pustaka 


\section{Pendahuluan}

Swamedikasi adalah pemilihan dan penggunaan obat-obatan oleh individu untuk mengobati penyakit atau gejala yang dikenali sendiri tanpa pengawasan medis dan terbukti aman dan efektif ${ }^{1,2}$. Tindakan swamedikasi meliputi penggunaan obat-obatan yang didapat tanpa resep dokter, pengulangan resep, membagikan obat-obatan dengan saudara atau keluarga, atau menggunakan obat sisa yang disimpan dirumah ${ }^{3,4}$. Obatobatan yang dapat digunakan dalam swamedikasi meliputi obat bebas, obat bebas terbatas, dan obat wajib apotek (OWA) .

Penggunaan antibiotik yang tidak tepat sering dilakukan dalam swamedikasi6. Berdasarkan hasil Riskesdas tahun 2013, 86,1\% rumah tangga menyimpan antibiotik yang diperoleh tanpa resep. Antibiotik digunakan untuk megobati gejala-gejala ringan seperti flu, batuk, demam, sakit tenggorokan dan penggunaannya kurang dari 5 hari ${ }^{7}$. Penggunaan antibiotik menurut Handayani tahun 2013, yang tidak tepat meliputi tidak tepat indikasi, tidak tepat obat, tidak tepat dosis, dan tidak tepat durasi dapat menyebabkan efek samping dan resistensi terhadap antibiotik.

Salah satu upaya untuk mencegah ketidaktepatan penggunaan antibiotik dapat dilakukan dengan melakukan surveilans pola penggunaan yang bertujuan untuk memperoleh gambaran penggunaan antibiotik secara kualitatif dan kuantitatif, mengidentifikasi faktor-faktor yang berpengaruh, serta melakukan evaluasi penggunaan antibiotik. Tindakan tersebut penting dilakukan agar dapat mengambil keputusan dalam mengendalikan penggunaan antibiotik yang tidak tepat sehingga dapat mengurangi beban pelayanan medis, waktu tunggu dibandingkan berobat ke dokter, biaya perawatan ${ }^{8}$.

Swamedikasi tidak tepat sering dilakukan oleh berbagai kalangan, tak terkecuali mahasiswa ${ }^{9}$. Berdasarkan penelitian di Universitas Udayana menunjukkan $67,5 \%$ mahasiswa kedokteran dan 19,2\% mahasiswa non-kedokteran pernah menggunakan antibiotika secara mandiri. Hasil studi menunjukkan penggunaan antibiotik dalam swamedikasi diindikasikan untuk menurunkan demam ${ }^{10}$.

Kajian penggunaan antibiotik dalam swamedikasi pada mahasiswa di Kota Mataram masih terbatas, tak terkecuali di Universitas Mataram. Universitas Mataram sebagai PTN tunggal di Kota Mataram memiliki mahasiswa yang beragam baik dari asal daerah maupun fakultas. Berdasarkan uraian diatas mendorong penelitian terkait pola penggunaan antibiotik dalam swamedikasi tahun 2017. Penelitian ini diharapkan dapat menggambarkan penggunaan antibiotik dalam swamedikasi.

\section{Metode}

A. Rancangan Penelitian: Penelitian ini merupakan penelitian deskriptif menggunakan desain potong lintang dengan pendekatan kualitatif dan kuantitatif. Penelitian dilaksanakan pada bulan Maret-Juli 2018 di Unit Pelaksana Tahun Pertama Bersama.

B. Sampel Penelitian: Sampel penelitian adalah mahasiswa TPB. Sejumlah 400 sampel dipilih secara acak ${ }^{11}$.

C. Kriteria sampel: Sampel penelitian terdaftar sebagai mahasiswa TPB Universitas 
Mataram, berusia 17-18 tahun, pernah menggunakan antibiotik dalam swamedikasi, bersedia menjadi responden. Mahasiswa yang tidak bersedia dan tidak pernah menggunakan antibiotik dalam swamedikasi tidak diikut sertakan dalam penelitian.

D. Instrumen penelitian: Penelitian ini menggunakan kuesioner yang diadaptasi dari studi literatur ${ }^{7,12}$. Kuesioner terdiri dari dua aspek, yaitu aspek sosiodemografi dan tingkat pengetahuan. Aspek sosiodemografi meliputi nama responden, umur, jenis kelamin, fakultas, tempat tinggal, asal sekolah dan kontak responden. Tingkat pengetahuan pengetahuan tentang antibiotik meliputi indikasi, regimen dosis ditinjau dari frekuensi dan durasi pemberian, resistensi,sumber memperoleh dan efek samping.

E. Variabel penelitian. Terdiri dari variabel dependen yaitu penggunaan antibiotik dalam swamedikasi, dan variabel independen yaitu tingkat pengetahuan tentang penggunaan antibiotik.

F. Analisis data. Analisis data dilakukan secara deskriptif. Data sosiodemografi dan pola penggunaan antibiotik dianalisis secara deskriptif berupa frekuensi dan persentase.

\section{Hasil dan Pembahasan}

\section{A. Karakteristik Demografi}

Sebanyak 421 mahasiswa TPB terlibat dalam penelitian. Dari total tersebut diperoleh 379 mahasiswa pernah dan 42 lainnya tidak pernah menggunakan antibiotik. Berdasarkan hasil penelitian responden terdiri dari 143 laki-laki dan 278 perempuan dengan rata-rata usia 17-18 tahun. Latar belakang responden sebagian besar berasal dari SMA. Deskripsi karakteristik demografi responden disajikan dalam Tabel 1.

Tabel 1. Karakteristik Demografi

\begin{tabular}{l|c|c|}
\multicolumn{1}{|c|}{$\begin{array}{c}\text { Karakteristik } \\
\text { Responden }\end{array}$} & Jumlah (n) & Persentase \\
\hline Jenis kelamin & 143 & $34,0 \%$ \\
\hline Laki-laki & 278 & $66,0 \%$ \\
\hline Perempuan & & \\
\hline Umur & 246 & $58,4 \%$ \\
\hline $17-18$ tahun & 175 & $41,6 \%$ \\
\hline 19-21 tahun & & \\
\hline Asal sekolah & 361 & $85,7 \%$ \\
\hline SMA & 45 & $10,7 \%$ \\
\hline MA & 15 & $3,6 \%$ \\
\hline SMK & 264 & $62,7 \%$ \\
\hline Fakultas/Prodi & 157 & $37,3 \%$ \\
\hline Kesehatan & & \\
\hline Non Kesehatan & 304 & $72,2 \%$ \\
\hline Alamat & 117 & $27,8 \%$ \\
\hline Lombok & & \\
\hline Luar Lombok & & \\
\hline
\end{tabular}

B. Pola Penggunaan Antibiotik dalam Swamedikasi

Pola penggunaan antibiotik diperoleh dari responden yang memiliki pengalaman dalam penggunaan antibiotik. Pengalaman penggunaan antibiotik yang dimaksudkan 
responden mengenal antibiotik dan dapat menyebutkan contoh antibiotik.

Berdasarkan 379 mahasiswa yang pernah menggunakan antibiotik didapatkan 12,7\% tidak mengenal antibiotik. 13,3\% salah menyebutkan jenis antibiotik yaitu sebagai obat analgesik. Antibiotik yang disering digunakan adalah amoksisilin $(87,7 \%)$. Pola penggunaan antibiotik disajikan pada Tabel 2.

Tabel 2. Pola Penggunaan Antibiotik dalam Swamedikasi pada Mahasiswa TPB Universitas Mataram

\begin{tabular}{|c|c|c|c|}
\hline No & Pola penggunaan antibiotik dalam swamedikasi & $\begin{array}{c}\text { Jumlah }(n)= \\
379\end{array}$ & $\begin{array}{c}\text { Frekuensi } \\
\text { (\%) }\end{array}$ \\
\hline 1. & $\begin{array}{l}\text { Alasan anda menggunakan antibiotik secara mandiri? } \\
\text { a. Murah } \\
\text { b. Mudah didapatkan } \\
\text { c. Malas berobat ke dokter } \\
\text { d. Pengalaman sebelumnya }\end{array}$ & $\begin{array}{c}24 \\
180 \\
46 \\
129\end{array}$ & $\begin{array}{c}6,3 \\
47,5 \\
12,1 \\
34\end{array}$ \\
\hline 2. & $\begin{array}{l}\text { Dalam kondisi apa anda menggunakan antibiotik? } \\
\text { a. Batuk-pilek } \\
\text { b. } \quad \text { Sakit tenggorokan-sakit gigi } \\
\text { c. Infeksi } \\
\text { d. } \quad \text { Demam }\end{array}$ & $\begin{array}{l}163 \\
69 \\
86 \\
61\end{array}$ & $\begin{array}{c}43 \\
18,2 \\
22,7 \\
16,1\end{array}$ \\
\hline 3. & $\begin{array}{l}\text { Penggunaan antibiotik didasarkan pada } \\
\text { a. } \quad \text { Rekomendasi oleh dokter/apoteker } \\
\text { b. } \quad \text { Saran teman atau keluarga } \\
\text { c. Pengalaman sebelumnya } \\
\text { d. Internet (media sosial) }\end{array}$ & $\begin{array}{l}188 \\
96 \\
84 \\
11\end{array}$ & $\begin{array}{c}49,6 \\
25,3 \\
22,2 \\
2,9\end{array}$ \\
\hline 4. & $\begin{array}{l}\text { Berapa lama anda menggunakan antibiotik tersebut? } \\
\text { a. 1-3 hari } \\
\text { b. } \quad 4-7 \text { hari } \\
\text { c. } \quad>7 \text { 7hari }\end{array}$ & $\begin{array}{c}254 \\
109 \\
16\end{array}$ & $\begin{array}{c}67,0 \\
28,8 \\
4,2\end{array}$ \\
\hline 5. & $\begin{array}{l}\text { Apakah anda selalu membaca kemasan obat sebelum digunakan? } \\
\text { a. Ya } \\
\text { b. Tidak pernah }\end{array}$ & $\begin{array}{c}338 \\
41\end{array}$ & $\begin{array}{l}89,2 \\
10,8\end{array}$ \\
\hline 6. & $\begin{array}{l}\text { Dimana anda membeli antibiotik untuk pengobatan mandiri? } \\
\text { a. Apotek } \\
\text { b. Toko obat } \\
\text { c. Sisa resep sebelumnya } \\
\text { d. Warung }\end{array}$ & $\begin{array}{c}334 \\
8 \\
25 \\
12\end{array}$ & $\begin{array}{c}88,1 \\
2,1 \\
6,6 \\
3,2\end{array}$ \\
\hline 7. & $\begin{array}{l}\text { Reaksi yang dialami jika menggunakan antibiotik berlebihan } \\
\text { a. Kemerahan (gatal-gatal) } \\
\text { b. Bengkak } \\
\text { c. } \quad \text { Sakit kepala } \\
\text { d. } \quad \text { Mual-muntah }\end{array}$ & $\begin{array}{c}90 \\
25 \\
128 \\
136\end{array}$ & $\begin{array}{c}23,7 \\
6,6 \\
33,8 \\
35,9\end{array}$ \\
\hline 8. & $\begin{array}{l}\text { Apa yang anda lakukan jika mengalami hal tersebut? } \\
\text { a. Berkonsultasi ke dokter/apoteker } \\
\text { b. } \quad \text { Berhenti minum antibiotik } \\
\text { c. Mengganti jenis antibiotik } \\
\text { d. } \quad \text { Menggunakan antibiotik } 2 \text { kali dosis sebelumnya }\end{array}$ & $\begin{array}{c}196 \\
166 \\
13 \\
4\end{array}$ & $\begin{array}{c}51,7 \\
43,8 \\
3,4 \\
1,1\end{array}$ \\
\hline
\end{tabular}


Berdasarkan Tabel 2 menunjukkan 47,5\% antibiotik digunakan secara mandiri karena mudah didapatkan. Kemudahan memperoleh antibiotik dapat disebabkan karena ketersediaan antibiotik tinggi, penyedia mengizinkan penjualan antibiotik tanpa resep serta komitmen bersama oleh pihak- pihak tertentu terkait penggunaan antibiotik dengan resep masih kurang serta lebih terjangkau dibandingkan berobat ke dokter.

Antibiotik digunakan untuk mengobati keluhan infeksi saluran pernafasan atas. Beberapa responden menunjukkan penggunaan antibiotik sudah tepat untuk mengobati penyakit infeksi. Responden beranggapan antibiotik efektif untuk mengatasi gejala ringan seperti batuk, pilek, sakit tenggorokan, dan demam, serta dapat mempercepat kesembuhan ${ }^{4,13}$.

Penggunaan antibiotik dalam penelitian ini berdasarkan rekomendasi oleh dokter atau apoteker, saran teman atau keluarga, pengalaman sebelumnya, dan informasi yang diperoleh dari media massa. Responden beranggapan bahwa rekomendasi berdasarkan dokter atau apoteker merupakan sumber terpercaya terkait penggunaan obat $^{4}$.

Penggunaan berdasarkan saran teman atau keluarga dapat digunakan dalam mengambil keputusan pengobatan dengan mempertimbangkan setiap kondisi. Informasi dari internet atau iklan tidak menjadi pilihan responden dalam pengambilan keputusan terapi antibiotik untuk pengobatan mandiri.

Responden selalu membaca kemasan obat untuk menghindari kesalahan dalam menggunakan obat. Pernyataan tersebut perlu ditinjau kembali untuk memperjelas bentuk kemasan obat yang dimaksud responden.

Responden menggunakan antibiotik selama 1-3 hari. Tindakan tersebut disebabkan karena setiap responden menunjukkan perbaikan gejala dalam kurun waktu yang berbeda-beda.

Berdasarkan jawaban responden memperoleh antibiotik di apotek $(87,9 \%)$ dan toko obat $(2,1 \%)$, namun terdapat beberapa reponden memperoleh antibiotik diwarung dan sisa resep sebelumnya. Antibiotik lebih terjangkau jika diperoleh di warung, hal ini disebabkan karena kurang pengawasan dalam distribusi obat. Penggunaan sisa resep sebelumnya dapat disebabkan karena responden beranggapan gejala atau penyakit yang dialami mirip seperti sebelumnya ${ }^{14}$.

Efek samping yang terjadi berdasarkan hasil penelitian menunjukkan reaksi mual muntah $(35,9 \%)$, sakit kepala $(33,8 \%)$, bengkak $(6,6 \%)$, dan kemerahan $(23,7 \%)$. Hasil penelitian menunjukkan responden menyadari akan dampak penggunaan antibiotik yang tidak tepat ${ }^{4}$.

Berdasarkan jawaban responden, tindakan yang dilakukan jika mengalami reaksi tersebut diantaranya berhenti menggunakan antibiotik $(57,1 \%)$, berkonsultasi ke dokter/ apoteker $(43,8 \%)$, namun terdapat beberapa responden mengganti jenis antibiotik dan menggunakan antibiotik 2 kali dosis sebelumnya. Penggantian jenis antibiotik dan penggunaan 2 kali dosis sebelumnya dapat meningkatkan bakteri kebal sehingga berdampak pada biaya perawatan meningkat ${ }^{15}$. 


\section{Kesimpulan}

Pola penggunaan antibiotik dalam swamedikasi oleh mahasiswa TPB untuk mengobati gejala flu dan batuk selama 1-3 hari berdasarkan rekomendasi tenaga kesehatan. Antibiotik digunakan karena mudah diperoleh di apotek. Efek samping penggunaan antibiotik berlebihan dapat menyebabkan mual muntah, sehingga dihentikan apabila efek samping terjadi dan berkonsultasi ke dokter.

\section{Daftar Pustaka}

1. WHO. 1998. The Role of the Pharmacist in Self-Care and Self-Medication. Oslo: WHO.

2. WSMI. 2017. Self Medication. Diakses dari http://www.wsmi.org/about-self-care and-self-medication/what-is-self-medication/ pada tanggal 2 Desember 2017.

3. Zafar, S.N., Syed, R., Waqar, S., Zubairi, A.J., dan Vaqar, T. 2008. Self-medication amongst university students of Karachi: Prevalence, knowledge, and attitudes. Journal of Pakistan Medical Association, Vol. 58 No.4, p. 214.

4. Shah, S.J., Ahmad, H., Rehan, R.B., Najeeb, S., Mumtaz, M., Jilani, M.H., Rabbani, M.S., Alam, M.Z., Farooq, S., dan Kadir, M.M., 2014. Self-medication with antibiotic among non-medical university students of Karachi: a cross-sectional study. Journal of Pharmaceutical Health Care and Sciences, Vol. 15 No.75, p. 1.

5. Rikomah, S.E., 2016. Farmasi Klinik Edisi ke-1. Yogyakarta: Deepublish, hal 158166.

6. Restiyono, Ady. 2016. Analisis Faktor yang Berpengauh dalam Swamedikasi Antibiotik pada lbu Rumah Tangga di Kelurahan Kajen Kabupaten Pekalongan. Jurnal Promosi Kesehatan Indonesia. 11(1), 14.

7. Widayati, A., 2011, Self medication with antibiotics in Yogyakarta City Indonesia, Thesis: Faculty of Health Sciences, University of Adelaide.

8. Helal, R.M., dan Abou-Elwafa, H.S. 2016. Self-Medication in University Students from the City of Mansoura, Egypt. Journal of Environmental and Public Health, Vol. 2017, No. 3, p 1.

9. Almasdy, D., dan Sharrif, A., 2011. Self medication practice with nonprescription medication among university student: a review of the literature. Archives of Pharmacy Practice, Vol. 2 No. 3, pp. 95-100.

10. Artini, I.G.A., dan Indrayani, A.W., 2016. Penggunaan Antibiotik Secara Mandiri Pada Mahasiswa Kedokteran dan Non Kedokteran Universitas Udayana. Archive of Community Health. Vol. 3 No. 2, hal. 22-9.

11. Sastroasmoro, S., dan Ismael, S., 1995. Eds. Dasar-Dasar Metodologi Penelitian Klinis_Edisi kedua. Jakarta: CV Sagung Seto.

12. Khanam, P., dan Haj-ali D. 2017. Assessment Of The Knowledge And Self Medication_Behaviours Towards Antibiotics among Nursing Students at King Saud Bin Abdulaziz University for Health Sciences, Al Ahsa. Journal of Nursing and Care, Vol. 6, Iss. 6, pp. 2-6.

13. Pal, B., Murni, K., Gupta, A.K., Choudhury, U., Rastogi, M., Pandey, H., Lal, C.K., Pandey, K., dan Das, P., 2016. Self Medication with Antibiotic Among Medical and Pharmacy Students in North India. Current Research in Medicine, Vol. 7 No. 2, pp 10-11. 
14. Buke, C., Hosgor-Limoncu, M., Ermertcan, S., Ciceklioglu, M., Tuncel, M., Kose, T., dan Eren, S., 2005. Irrational Use of Antibiotic Among University Students. Journal of Infection, Vol. 2005 No. 51, pp. 137-8.

15. Lior, C., dan Bjerrum, L., Antimicrobial resistance: risk associated with antibiotic overuse and initiatives to reduce the problem. Therapeutic Advances in Drug Safety, Vol. 5 No. 6, pp. 230-1. 